\title{
Calvarial tuberculosis: A report of eleven patients
}

\author{
Batuk Diyora, Rajiv Kumar, Rahul Modgi, Alok Sharma \\ Department of Neurosurgery, L.T.M.G. Hospital, Mumbai, India
}

\author{
Address for correspondence: \\ Dr. Batuk Diyora, \\ Department of Neurosurgery, \\ $2^{\text {nd }}$ Floor, L.T.M.G. Hospital, \\ Sion (W), Mumbai - 400 022, India. \\ E-mail: bddiyora@hotmail.com
}

PMID: 19934560

DOI: $10.4103 / 0028-3886.57814$

\begin{abstract}
Background: Tuberculosis is endemic in developing countries. However, calvarial tuberculosis is rare, even in areas where tuberculosis is endemic. In the literature, only few case series of calvarial tuberculosis have been reported. Aim: To report a case series of I I patients with calvarial tuberculosis, and discuss their presentation and management. Materials and Methods: This study is a retrospective analysis of case records of 1 I patients with calvarial tuberculosis treated between $200 \mathrm{I}$ and 2005 in a tertiary hospital. Clinical features, radiological findings, surgical and medical management, and outcomes were reviewed. Results: Of the 11 patients, seven were male and the age ranged between I and 25 years (mean 15.09 years). The mean duration of symptoms was 2.9 months (range I-5 months). The most common presenting features were scalp swelling, discharging sinus, and pain. Computed tomography (CT) scan of brain showed punched out bony defect, with a peripherally enhancing extradural collection in most of the cases. Ten patients underwent surgical excision of necrotic bone and granulation tissue with primary closure of the scalp flap and antituberculous therapy. One patient is being managed with antituberculous therapy only. Of the 10 patients treated surgically and with antituberculous therapy, nine recovered well and one died of tuberculous meningitis and hydrocephalus. The patient being treated with antituberculous therapy is under follow-up. Conclusion: A high index of suspicion and knowledge is reQuired for early diagnosis of calvarial tuberculosis. Surgery and antituberculous therapy remains the mainstay of treatment.
\end{abstract}

Key words: Antitubercular therapy, calvarium, granulomas, tuberculosis

\section{Introduction}

Mycobacterium tuberculosis infection is still endemic in developing countries. With the resurgence of immunocompromized states like human immunodeficiency virus infection (HIV), incidence of tuberculosis is also increasing in developed countries. Involvement of the calvarium in tubercular disease is rare, and even rarer is primary calvarial tuberculosis, with no evidence of tuberculosis elsewhere in the body..$^{[1-4]}$ We report a series of 11 cases of calvarial tuberculosis and present the clinical features, radiology, histopathology, and operative findings.

\section{Materials and Methods}

This is a retrospective analysis of 11 patients of calvarial tuberculosis treated between 2001 and 2009 in a tertiary hospital. Details of history and clinical examination in all the cases were reviewed. Laboratory investigations and imaging were analyzed. Indications for surgical intervention, medical management and outcomes were also analyzed.

\section{Results}

The age of the patients ranged from one year to 25 years (mean 15.09 years). Out of 11 patients, seven were male. The duration of symptoms ranged from one month to five months (mean 2.9 months). Nine patients presented with swelling over scalp [Figures 1a and $b, 2 a$ and $b]$, while two patients presented with swelling and discharging sinus [Figure 3]. Two patients had family history of pulmonary tuberculosis (PTB), while one patient had associated PTB. 


\begin{tabular}{|c|c|c|c|c|c|c|}
\hline Age/sex & Clinical features & CT scan & $\begin{array}{l}\text { Lab. } \\
\text { investigation }\end{array}$ & Management & $\begin{array}{l}\text { Operative } \\
\text { findings }\end{array}$ & Outcome \\
\hline $25 / M$ & $\begin{array}{l}\text { Swelling over Lt. FP } \\
\text { region- } 3 \text { months. } \\
\text { Headache- } 3 \text { months }\end{array}$ & $\begin{array}{l}\text { Extradural collection } \\
\text { in Lt. FP region with } \\
\text { punched out defect in } \\
\text { Lt. Frontal bone }\end{array}$ & $\begin{array}{l}\text { Elevated ESR } \\
\text { Mantoux test } \\
\text { positive }\end{array}$ & $\begin{array}{l}\text { Surgical excision } \\
\text { followed by } 4 \text { drugs } \\
\text { AKT for } 2 \text { months } \\
\text { and } 2 \text { drugs AKT for } \\
10 \text { months }\end{array}$ & $\begin{array}{l}\text { Excision of } \\
\text { necrotic bone and } \\
\text { granulation tissue } \\
\text { with primary } \\
\text { closure of skin flap }\end{array}$ & Recovered \\
\hline $18 / \mathrm{F}$ & $\begin{array}{l}\text { Pus discharging sinus } \\
\text { over Rt. Occipital } \\
\text { region }-1 \text { month }\end{array}$ & $\begin{array}{l}\text { Eroded Rt. Occipital } \\
\text { bone with underlying } \\
\text { ring-enhancing ED } \\
\text { collection }\end{array}$ & $\begin{array}{l}\text { Elevared ESR } \\
\text { Mantoux test } \\
\text { positive }\end{array}$ & $\begin{array}{l}\text { Surgical excision } \\
\text { followed by } 4 \text { drugs } \\
\text { AKT for } 2 \text { months } \\
\text { and } 2 \text { drugs AKT for } \\
10 \text { months }\end{array}$ & $\begin{array}{l}\text { Excision of } \\
\text { necrotic bone and } \\
\text { granulation tissue } \\
\text { with primary } \\
\text { closure of skin flap }\end{array}$ & Recovered \\
\hline 20/M & $\begin{array}{l}\text { Swelling over Rt. Frontal } \\
\text { region-1 month }\end{array}$ & $\begin{array}{l}\text { Punched out defect } \\
\text { in right frontal bone } \\
\text { with ring-enhancing } \\
\text { extradural collection }\end{array}$ & $\begin{array}{l}\text { Elevated ESR } \\
\text { Mantoux test } \\
\text { positive }\end{array}$ & $\begin{array}{l}\text { Surgical excision } \\
\text { followed by } 4 \text { drugs } \\
\text { AKT for } 2 \text { months } \\
\text { and } 2 \text { drugs AKT for } \\
10 \text { months }\end{array}$ & $\begin{array}{l}\text { Excision of } \\
\text { necrotic bone and } \\
\text { granulation tissue } \\
\text { with primary } \\
\text { closure of skin flap }\end{array}$ & Recovered \\
\hline $4 / M$ & $\begin{array}{l}\text { Swelling over left } \\
\text { forehead- } 3 \text { months, } \\
\text { discharging sinus right } \\
\text { side of neck- } 3 \text { months } \\
\text { Known case of PTB and } \\
\text { on AKT }\end{array}$ & $\begin{array}{l}\text { Bone eroding mass } \\
\text { involving lesion left } \\
\text { frontal bone with } \\
\text { enhancing extradural } \\
\text { collection }\end{array}$ & $\begin{array}{l}\text { Elevated ESR } \\
\text { Mantoux test } \\
\text { positive }\end{array}$ & $\begin{array}{l}\text { Surgical excision } \\
\text { followed by } 4 \text { drugs } \\
\text { AKT for } 2 \text { months } \\
\text { and } 2 \text { drugs AKT for } \\
12 \text { months }\end{array}$ & $\begin{array}{l}\text { Excision of } \\
\text { necrotic bone and } \\
\text { granulation tissue } \\
\text { with primary } \\
\text { closure of skin flap }\end{array}$ & $\begin{array}{l}\text { Died - } \\
\text { developed } \\
\text { tubercular } \\
\text { meningitisand } \\
\text { hydrocephalus }\end{array}$ \\
\hline $15 / M$ & $\begin{array}{l}\text { Swelling over occipital } \\
\text { region- } 4 \text { months, pain } \\
\text { over left forehead-4 } \\
\text { months }\end{array}$ & $\begin{array}{l}\text { Bony defect with } \\
\text { peripheral, enhancing, } \\
\text { extradural collection } \\
\text { over occipital region }\end{array}$ & $\begin{array}{l}\text { Elevated ESR } \\
\text { Mantoux test } \\
\text { positive }\end{array}$ & $\begin{array}{l}\text { Surgical excision } \\
\text { followed by } 4 \text { drugs } \\
\text { AKT for } 2 \text { months } \\
\text { and } 2 \text { drugs AKT for } \\
10 \text { months }\end{array}$ & $\begin{array}{l}\text { Excision of } \\
\text { necrotic bone and } \\
\text { granulation tissue } \\
\text { with primary } \\
\text { closure of skin flap }\end{array}$ & Recovered \\
\hline $20 / \mathrm{F}$ & $\begin{array}{l}\text { Swelling over left } \\
\text { forehead- } 4 \text { months }\end{array}$ & $\begin{array}{l}\text { Bony defect with } \\
\text { peripheral enhancing, } \\
\text { extradural collection }\end{array}$ & $\begin{array}{l}\text { Elevated ESR } \\
\text { Mantoux test } \\
\text { positive }\end{array}$ & $\begin{array}{l}\text { Surgical excision } \\
\text { followed by } 4 \text { drugs } \\
\text { AKT for } 2 \text { months } \\
\text { and } 2 \text { drugs AKT for } \\
10 \text { months }\end{array}$ & $\begin{array}{l}\text { Excision of } \\
\text { necrotic bone and } \\
\text { granulation tissue } \\
\text { with primary } \\
\text { closure of skin flap }\end{array}$ & Recovered \\
\hline $1 / M$ & $\begin{array}{l}\text { Swelling over left } \\
\text { forehead- } 2 \text { months, had } \\
\text { family history of PTB }\end{array}$ & $\begin{array}{l}\text { Enhancing extra- } \\
\text { calvarial collection } \\
\text { with punched out } \\
\text { defect in fronto- } \\
\text { temporal bone }\end{array}$ & $\begin{array}{l}\text { Elevated ESR } \\
\text { Mantoux test } \\
\text { positive }\end{array}$ & $\begin{array}{l}\text { Surgical excision } \\
\text { followed by } 4 \text { drugs } \\
\text { AKT for } 2 \text { months } \\
\text { and } 2 \text { drugs AKT for } \\
10 \text { months }\end{array}$ & $\begin{array}{l}\text { Fronto- temporal } \\
\text { craniotomy } \\
\text { with excision of } \\
\text { necrotic bone and } \\
\text { granulation tissue } \\
\text { with primary } \\
\text { closure of skin flap }\end{array}$ & Recovered \\
\hline $16 / M$ & $\begin{array}{l}\text { Swelling over scalp-4 } \\
\text { months }\end{array}$ & $\begin{array}{l}\text { Bony defect with } \\
\text { peripherally } \\
\text { enhancing extradural } \\
\text { collection }\end{array}$ & $\begin{array}{l}\text { Elevated ESR } \\
\text { Mantoux test } \\
\text { positive }\end{array}$ & $\begin{array}{l}\text { Surgical excision } \\
\text { followed by } 4 \text { drugs } \\
\text { AKT for } 2 \text { months } \\
\text { and } 2 \text { drugs AKT for } \\
10 \text { months }\end{array}$ & $\begin{array}{l}\text { Excision of } \\
\text { necrotic bone and } \\
\text { granulation tissue } \\
\text { with primary } \\
\text { closure of skin flap }\end{array}$ & Recovered \\
\hline $25 / \mathrm{F}$ & $\begin{array}{l}\text { Swelling over left side of } \\
\text { forehead- } 5 \text { months }\end{array}$ & $\begin{array}{l}\text { Bony defect with } \\
\text { peripherally } \\
\text { enhancing extradural } \\
\text { collection which } \\
\text { was attached to a } \\
\text { small ring-enhancing } \\
\text { intradural lesion }\end{array}$ & $\begin{array}{l}\text { Elevated ESR } \\
\text { Mantoux test } \\
\text { positive }\end{array}$ & $\begin{array}{l}\text { Surgical excision } \\
\text { followed by } 4 \text { drugs } \\
\text { AKT for } 2 \text { months } \\
\text { and } 2 \text { drugs AKT for } \\
10 \text { months }\end{array}$ & $\begin{array}{l}\text { Excision of } \\
\text { necrotic bone and } \\
\text { granulation tissue } \\
\text { with primary } \\
\text { closure of skin } \\
\text { flap. Intradural } \\
\text { component left } \\
\text { untouched }\end{array}$ & Recovered \\
\hline $10 / \mathrm{F}$ & $\begin{array}{l}\text { Swelling and pain over } \\
\text { right side of scalp- } 4 \\
\text { months }\end{array}$ & $\begin{array}{l}\text { Bony defect with } \\
\text { peripherally } \\
\text { enhancing extradural } \\
\text { collection in right } \\
\text { parietal region }\end{array}$ & - & $\begin{array}{l}\text { Surgical excision } \\
\text { followed by } 4 \text { drugs } \\
\text { AKT for } 2 \text { months } \\
\text { and } 2 \text { drugs AKT for } \\
10 \text { months }\end{array}$ & $\begin{array}{l}\text { Excision of } \\
\text { necrotic bone and } \\
\text { granulation tissue } \\
\text { with primary } \\
\text { closure of skin flap }\end{array}$ & Recovered \\
\hline $12 / M$ & $\begin{array}{l}\text { Periorbital swelling-1 } \\
\text { month, discharging } \\
\text { sinus over left cheek-1 } \\
\text { week, father had PTB }\end{array}$ & $\begin{array}{l}\text { Lytic lesion over left } \\
\text { supra-orbital margin } \\
\text { and adjoining fronto- } \\
\text { temporal bone with } \\
\text { large subgaleal and } \\
\text { small extradural } \\
\text { collection }\end{array}$ & $\begin{array}{l}\text { Elevated ESR } \\
\text { Mantoux test } \\
\text { positive }\end{array}$ & $\begin{array}{l}\text { Being managed } \\
\text { conservatively with } \\
\text { AKT }\end{array}$ & - & $\begin{array}{l}\text { Recovering at } \\
\text { follow-up }\end{array}$ \\
\hline
\end{tabular}




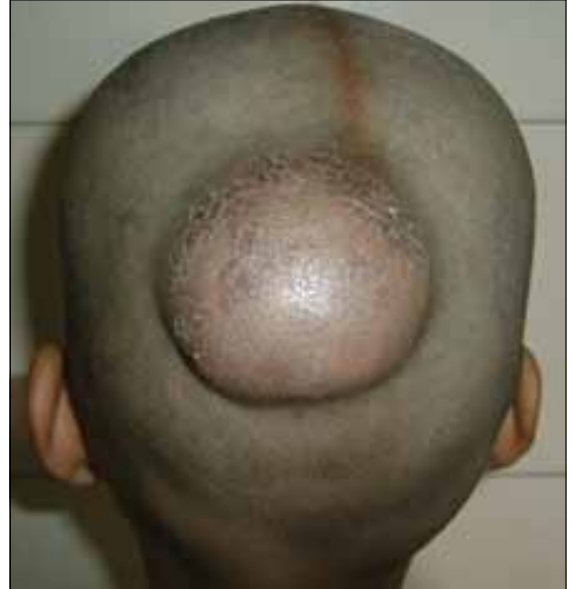

Figure 1a: Photograph of case 5 showing swelling over the occipital region

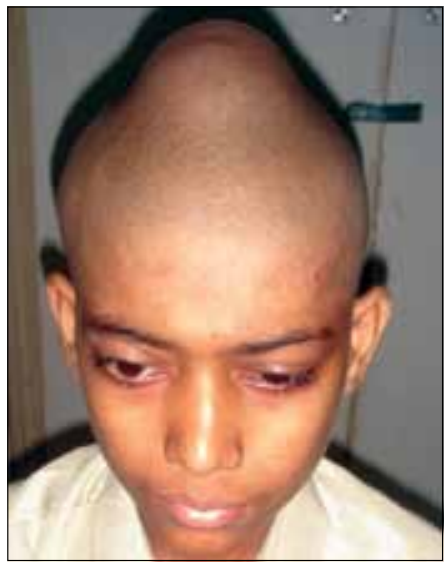

Figure 2a: Photograph of case 8 showing swelling over the scalp

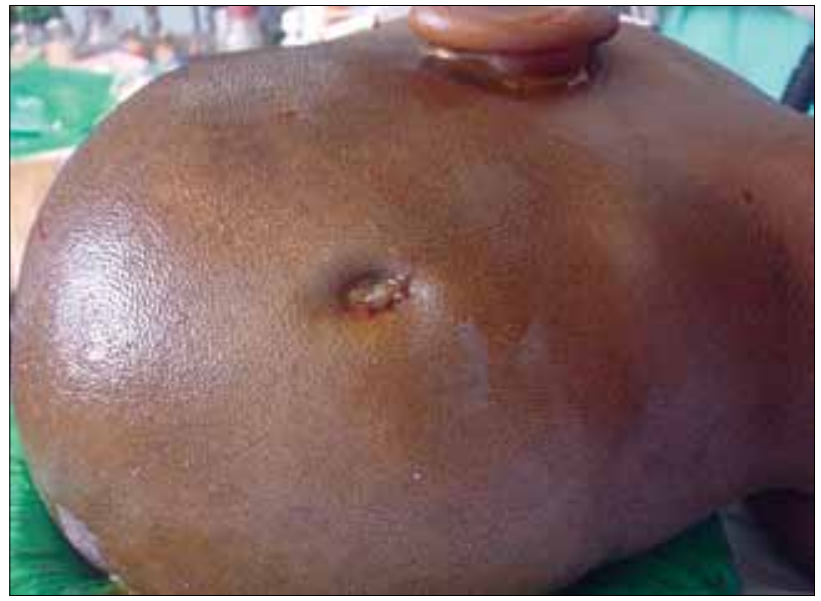

Figure 3: Picture of case 2 showing discharging sinus over the right occipital region

Computed tomography (CT) of brain done in all the patients, showed punched out bony defects with extradural ring-enhancing collection [Figure 4a and b]. One patient [Patient 9] had small parenchymal lesion

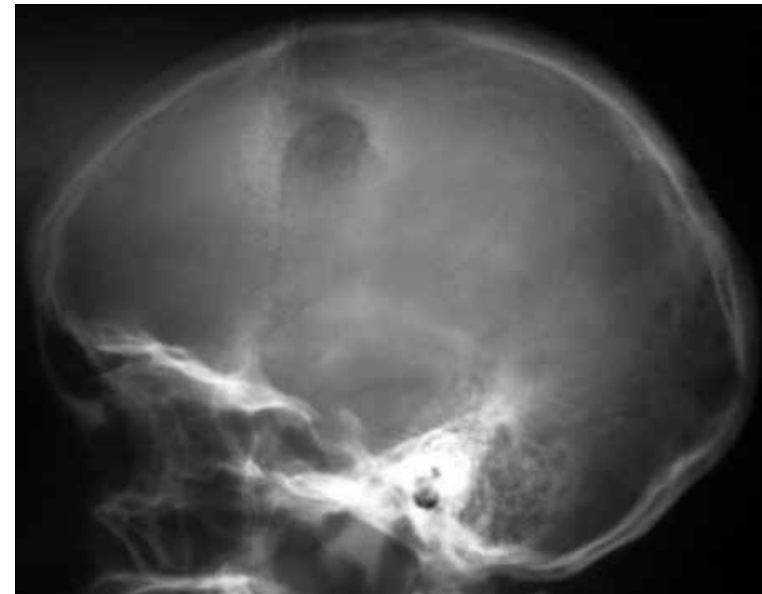

Figure 1b: X-ray skull of case 5 showing punched out lesion

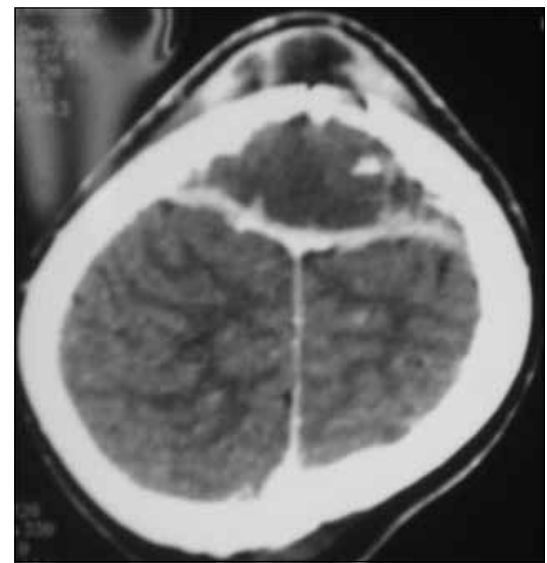

Figure 2b: Contrast-enhanced computed tomography of case 8 showing bony defect, with a peripherally enhancing extradural collection

just beneath the extradural component [Figure 5]. The lesions were involving predominantly frontal bones. The erythrocyte sedimentation rate was elevated in all the patients, and Mantoux test was positive in 10 patients.

All patients except one (Patient 11), underwent surgery for large extradural collection. Scalp flap was marked over normal skin including the area of lesion, and elevated with proper care. At operation bony erosion was noted along with necrotic yellowish caseating material coming out through the bony defect [Figure 4c]. Craniotomy was performed, and all abnormal extradural granulomatous tissue which was adherent to the dura was excised. The dura was left untouched in all cases, even in patient 9, who had small intradural component. Thorough toileting of wound was done with betadine and hydrogen peroxide. Primary skin flap closure was done. Wound healed well in all cases.

Acid-fast bacilli were seen on Ziehl Nielsen smear in only a few cases, in most of the cases acid-fast bacilli could not be demonstrated because of necrosis. Microscopic 


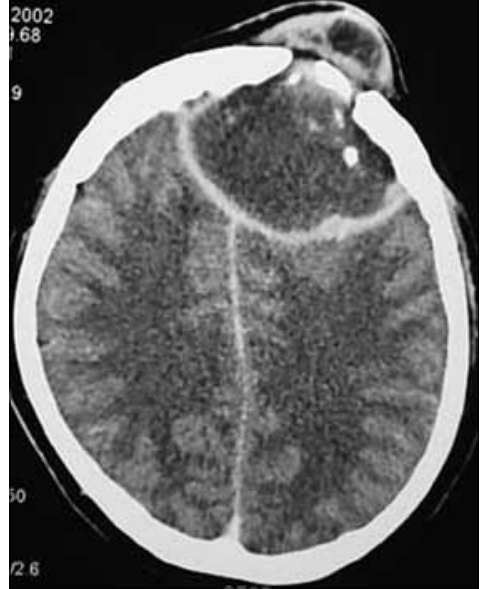

Figure 4a: Computed tomography scan (axial view) of case 1 showing extradural collection in left frontoparietal region with punched out defect in the left frontal bone

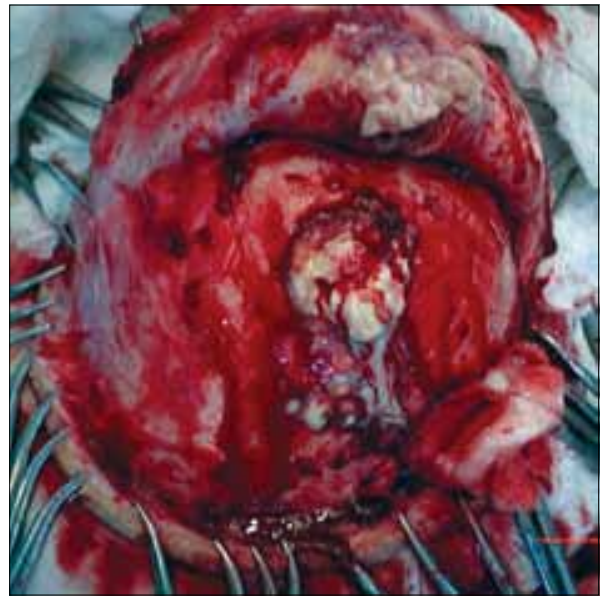

Figure 4c: Intraoperative picture of Case 1 showing yellowish caseating pus coming out through circumscribed bony defect

examination showed lymphocytes, plasma cells and focal polymorphnuclear cells with proliferating blood vessels. Histopathological examination revealed granulomatous lesion of tuberculous etiology in all cases.

Postoperatively all patients were kept on antitubercular therapy. All patients were given isoniazid, rifampicin, ethambutol and pyrazinamide for four months followed by isoniazid and rifampicin for 10 to 12 months depending upon clinicopathoradiological response. All patients except one had good outcome following surgery and antitubercular treatment. One patient (Patient 4) expired, due to tubercular meningitis and hydrocephalus.

\section{Discussion}

Advances in the field of medicine often change the distribution and impact of a disease, the most common

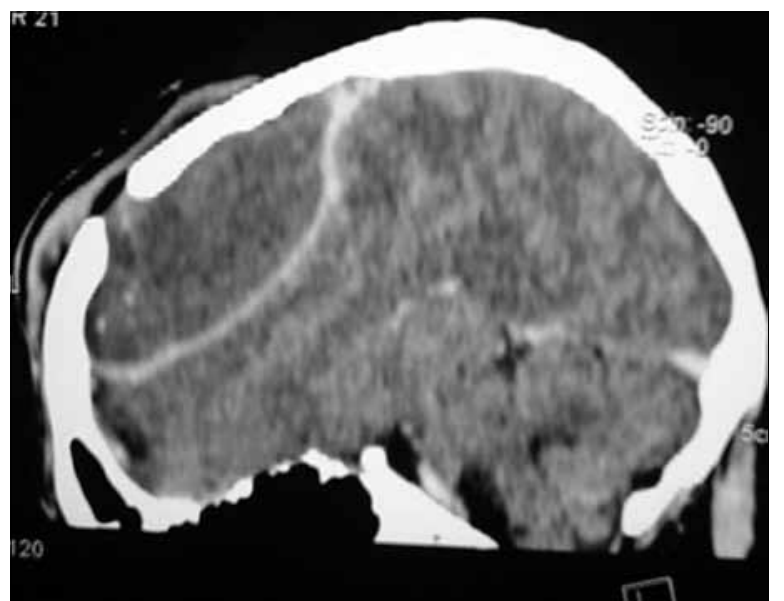

Figure 4b: Computed tomography scan (sagittal view) of case 1 showing extradural collection in left frontoparietal region with punched out defect in the left frontal bone

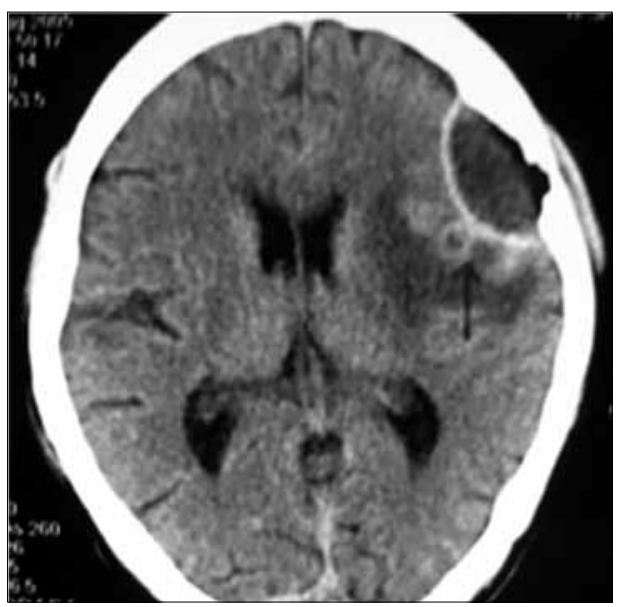

Figure 5: Contrast-enhanced computed tomography of case 9 showing bony defect, with a peripherally enhancing extradural collection, and small ring-enhancing intradural lesion attached with extradural component

example is tuberculosis. Once known as the white plague of centuries, tuberculosis is a condition that is today not only treatable but also preventable. Tuberculosis still poses a major health problem in developing countries. Tuberculosis affecting bone account for $1 \%$ of the tuberculosis infection, ${ }^{[1]}$ but only $0.2-1.3 \%$ of these are estimated to suffer from tuberculosis of the skull. ${ }^{[2-4]}$ Reid from Germany was the first to report skeletal tuberculosis in $1842 .{ }^{[4]}$ In 1933, Strauss reviewed 220 cases of calvarial tuberculosis reported in the literature till that date and added three of his own. ${ }^{[2]}$ Subsequent reported large case series include 40 cases by Weng and $\mathrm{Wu}$ in $1942^{[5]}$ and 22 cases by Mohanty et al., in 1981. ${ }^{[6]}$ A search of the available English literature through December 2000 revealed 365 reported cases of calvarial tuberculosis. ${ }^{[7]}$ Among the various forms of the central nervous system tuberculosis, calvarial tuberculosis is very rare. This rarity may be because of paucity of lymphatics in the calvarial bone. ${ }^{[3]}$ Also tuberculous bone lesions occur 
mainly in cancellous bones and flat bones of the skull. Comparatively the disease is rare in the skull. ${ }^{[8]}$

Isolated calvarial tuberculosis is rare, mostly it occurs secondary to hematogenous spread from the primary focus such as PTB, ${ }^{[2,5,6,9]}$ cervical or hilar lymphadenitis, ${ }^{[6]}$ renal or systemic tuberculosis. ${ }^{[10]}$ Less commonly it can arise from tuberculous mastoiditis or spinal tuberculosis. In our series only one patient exhibited extracalvarial primary focus of tuberculosis, PTB. In such patients the latent period for calvarial involvement is more than one year on an average. ${ }^{[2]}$ Primary event in the pathogenesis of calvarial tuberculosis is the lodging of bacilli in the diploic of skull bones via hematogenous spread from the extracalvarial focus. Further course depends on the host resistance and virulence of bacilli. If host resistance is low and virulence of the organism is high there is further proliferation of bacilli resulting in obliteration of capillaries and replacement of bone trabeculae by granulation tissue and concentrically placed proliferating fibroblasts. The outer table is usually the first to be destroyed, though eventually both tables can be affected. ${ }^{[11]}$ Trauma has also been incriminated to cause skeletal tuberculosis. The possible mechanisms include: rich vascularity of the skull bones or low resistence or trauma may unmask a latent infection. ${ }^{[12]}$

Volkmann, in 1880 studied 12 patients and defined the lesions. ${ }^{[13]}$ He called it as perforating tuberculosis of the skull. As described by him, this was a small, circumscribed punched out defect in the bone with granulation tissue covering both internal and external aspect with little tendency for osteitis to spread in the bone or periosteium surrounding the defect. ${ }^{[13]}$ Koening, in 1888 defined a type of tuberculosis of the skull which was less common than the perforating type, characterized by widespread destruction of the inner table with abundant extradural granulation tissue in the form of pachymeningitis externa and called it diffuse tuberculosis of the skull. ${ }^{[14]} \mathrm{He}$ described multiple complete perforations of the skull at some distance from each other, presumably linked by the deeper layer of granulations. However, the validity of this concept was challenged considering similarities of the two types to preclude their separation. ${ }^{[15]}$ The basis of the argument was presence of widespread diploic tuberculous infiltration in these cases. Mohanty et al., had reported the third and least common type, circumscribed and sclerotic type in which there is marked thickening of the bone because of lack of blood supply to the diseased bone. ${ }^{[6]}$

Younger population is at higher risk to develop calvarial tuberculosis and it is rare in infancy. About half of the patients reported in the literature were younger than 10 years of age, and $75-90 \%$ of the patients were younger than 20 years of age. ${ }^{[2,5,6]}$ In our series $60 \%$ of the patients were younger than 20 years of age. Prevalence of the disease is equal in both the sexes. The most common sites of involvement are frontal and parietal bones, both the bones have large amount of cancellous bone. ${ }^{[5]}$ In our series the most common site of involvement was frontal and parietal bones followed by occipital bone. Most common presentation is the painless, soft, fluctuant scalp swelling. ${ }^{[5,6,10,16,17]}$ Attachment to the skin, sinus formation, and discoloration are late features. Headache, if present, is usually localized to the site of infection. ${ }^{[7]}$ Rarely, patient may present with seizure ${ }^{[3]}$ or motor deficit. ${ }^{[15]}$ In our series the most common presentation was scalp swelling, discharging sinus, and pain. Sutures are not a strong barrier to spread but the dura usually prevents intradural extension. An extensive area of destruction occurs before clinical presentation. ${ }^{[18]}$ Symptoms related to intracranial extension are rare. In the series by Strauss, $4 \%$ had meningitis, and 2\% had cerebral involvement. ${ }^{[2]}$ In the series by Mang and $\mathrm{Wu}$ no of the 40 patients had intradural involvement. ${ }^{[5]}$ In our series one patient developed tuberculous meningitis.

Plain X-ray of the skull can be helpful. Areas of rarefaction are seen early in the disease, which develop into punched-out defects with a central sequestrum later on. ${ }^{[7]}$ Both osteolytic and osteoblastic areas may be seen. ${ }^{[19]}$ Rarely, sclerosis may be seen and indicates secondary infection. In a study of 42 patients by Raut et al., ${ }^{[20]}$ lesions were detected at conventional radiography in $34(80.95 \%)$ patients. CT depicted bone destruction in 36 patients (85.7\%). Extradural lesions and intraparenchymal pathologies were detected in 22 $(52.3 \%)$ patients and five (11.9\%) patients, respectively.

CT scan of the brain helps in assessing the extent of bone destruction, scalp swelling, and degree of intracranial involvement. ${ }^{[2]}$ While extradural collection enhances peripherally on administration of contrast. CT scan of the brain reveals extradural compression, if present, and helps to rule out associated intradural lesions such as tuberculoma, subdural empyema. ${ }^{[20]}$ The CT scan picture of tuberculous osteomyelitis is not very specific; and the differential diagnoses include pyogenic osteomyelitis, calvarial metastases, multiple myeloma, hemangioma, giant cell tumor or even an aneurysmal bone cyst and Langerhans cell histiocytosis. ${ }^{[19]}$

Demonstration of Acid-fast Bacilli (AFB) in pus smear by Ziehl-Nielsen staining or the isolation of mycobacterium by culture are diagnostic, ${ }^{[19]}$ but they are rarely seen. Microscopic examination usually indicates infiltration with lymphocytes, plasma cells and focal polymorphnuclear cells with proliferating blood vessels. Multiple epitheloid granulomas with Langerhans type giant cells can be observed with necrotic material. ${ }^{[2]} \mathrm{A}$ positive Mantoux test 
and raised ESR may give diagnostic clue for tuberculosis. However, Mantoux test may be negative in $10 \%$ patients, while the ESR may be normal in a similar proportion of patients. ${ }^{[22]}$ Erythrocyte sedimentation rate was increased and Mantoux test was positive in most of the patients in our series. Definitive diagnosis depends upon the histopathological finding of the bone lesions. ${ }^{[23]}$ In our patients, the diagnosis of tuberculosis was made on the basis of clinical findings, raised ESR, positive tuberculin skin test results, radiological features, and histology.

Treatment for calvarial tuberculosis includes surgery and antituberculous therapy. Surgical treatment alone showed good results before the advent of antituberculous chemotherapy. ${ }^{[2]}$ Although there are some reports in the literature favouring antituberculous therapy alone, ${ }^{[12,24]}$ recent studies indicate that combination treatment is better, as extensive areas of diseased bone may be a source of tuberculous bacilli unless surgically removed. ${ }^{[6,25]}$ Surgery is indicated to establish the diagnosis, to remove thick extradural granulation tissue and necrotic bone and in patients with sinus discharge ${ }^{[12]}$ intracranial extensions, ${ }^{[26]}$ and large collections of caseating material causing mass effect. ${ }^{[19]}$ Surgery is not indicated for small lesions, even in the presence of a sequestrum, provided there is a favorable response to chemotherapy. ${ }^{[15]}$ Surgical treatment includes an incision in normal skin with proper care in raising flap, excision of pus or necrotic tissue, excision of involved bone and extradural granulations. Dura should be left untouched. Sinus should be excised with primary skin closure. In our series, all except one patient underwent surgery because all had extensive areas of diseased bone with large extradural collection. We did not encounter any problem in wound healing in primary skin closure. Anti-tubercular therapy has to be continued for nine months to one year. ${ }^{[20]}$ The response to the drugs should be monitored by clinical examinations, ESR, and CT scanning. Radiological evidence of the healing is seen after about two months of chemotherapy, with new bone formation at the edges of the lesion. ${ }^{[19]}$ Clinical and radiological response to anti-tuberculous chemotherapy is usually good. ${ }^{[20]}$

Calvarial tuberculosis is a rare presentation of the common disease. Scalp swelling is the common presentation. Common CT scan findings are punched out bony defect, with a peripherally enhancing extradural collection. Combination of surgical excision and anti-tubercular therapy are the preferred treatment. With early diagnosis and a combination of surgical and medical management, all cases of calvarial tuberculosis are potentially curable.

\section{References}

1. Davidson PT, Horowitz I. Skeletal tuberculosis: A review with patient presentations and discussion. Am J Med 1970;48:77-84.

2. Strauss DC. Tuberculosis of the flat bones of vault of the skull. Surg Gynecol Obstet 1993;57:384-98.

3. Tirona JP. The roentgenological and pathological aspects of tuberculosis of the skull. Am J Roentgenol Radium Ther Nucl Med 1954;72:762-8.

4. Reid E. Medizinisches Correspondenzblatt BayerischerArzte Erlangen, $1842 ; 33$.

5. Meng CM, Wu YK. Tuberculosis of the flat bones of the vault of the skull. J Bone Joint Surg 1942;34:341-53.

6. Mohanty S, Rao CJ, Mukherjee KC. Tuberculosis of the skull. Int Surg 1981;66:81-3.

7. Mukherjee KK, Kaushik R, Nada R, Khosla VK, Khandelwal N, Kak VK. Calvarial tuberculosis. Surg Neurol 2002;57:195-203.

8. Agarwal N, Jain SK. Tuberculous osteitis of skull: A case report. Ind J Tub 2002;49:105-6.

9. Mishra SK, Nigam P. Tuberculosis of flat bones. Indian J Chest Dis Allied Sci 1984;26:174-6.

10 Rudman IE. Tuberculosis of the bones of the skull. Med Times 1965;93:910-3.

11. Malhotra R, Dinda AK, Bhan S. Tuberculous osteitis of the skull. Indian Pediatr 1993;30:1119-23.

12. LeRoux PD, Griffin GE, Marsh HT, Winn HR. Tuberculosis of the skull; A rare condition-Case report and review of the literature. Neurosurgery 1990;26:851-5.

13. Volkman R. Die perforierende Tuberkulose der Knochen das Schaldeldaches. Zentralbl Chir 1880;7:305-7.

14. Koening F. Traite de Pathologie et Chirurgie Speciale. Paris, Delahaye et Lecrosnier, 1888. p. 184.

15. Miles J, Hughes B. Tuberculosis osteitis of the skull. B J Surg 1970;57:673-9.

16. Barton CJ. Tuberculosis of the vault of the skull. Br J Radiol 1961;34:286-90.

17. Reddy RD, Ram Mohan S, Chari SK, SatyanarayanaK. Tubercular osteomyelitis of skull. Indian J Tuberc 1974;21:213-5.

18. Rajmohan BP, Anto Dominic, Alappat Jacob P. Calvarial tuberculosis. Neurol India 2004;52:278-9.

19. Gupta PK, Kolluri VR, Chandramouli BA, Venkataramana NK, Das B. Calvarial tuberculosis: A report of two cases. Neurosurgery 1989;25:830-3.

20. Raut AA, Nagar AM, Muzumdar D, Chawla AJ, Narlawar RS, Fattepurkar S, et al. Imaging Features of Calvarial Tuberculosis: A Study of 42 Cases. AJNR Am J Neuroradiol 2004;25:409-14.

21. Jadhav RN, Palande DA. Calvarial Tuberculosis. Neurosurgery $1999 ; 45: 1345-9$.

22. Fisk TL, Hon HM, Lennox IL, Fordham von Reyn C, Horsburgh CR Jr, et al. Detection of latent tuberculosis among HIV infected patients after initiation of highly active anti-retroviral therapy. AIDS 2003;12:1102-4.

23. Bardales RH, Stanley MW. Subcutaneous masses of the scalp and forehead: Diagnosis by fine-needle aspiration. Diagnostic Cytopathol 1995;12:131-4

24. Prinsloo JG, Kirsten G. Tuberculosis of the skull vault. S Afr Med J 1977;51:248-50.

25. Ip M, Tsui E, Wong KL, Jones B, Pung CF, Ngan H. Disseminated skletal tuberculosis with skull involvement. Tuberc Lung Dis 1993;74:211-4.

26. Tyagi AK, Kirollos RW, Kang NV. Tuberculous osteomyelitis of the skull: A case report and review of the literature. Br J Neurosurg 1996;10:399-401.

Accepted on 20-08-2009

Source of Support: Nil, Conflict of Interest: None declared. 